\title{
PARTISAN IMPACTS ON THE ECONOMY: \\ EVIDENCE FROM PREDICTION MARKETS AND CLOSE ELECTIONS
}

\author{
Erik Snowberg \\ Justin Wolfers \\ Eric Zitzewitz \\ Working Paper 12073 \\ http://www.nber.org/papers/w12073
}

\author{
NATIONAL BUREAU OF ECONOMIC RESEARCH \\ 1050 Massachusetts Avenue \\ Cambridge, MA 02138 \\ March 2006
}

(C) 2006 by Erik Snowberg, Justin Wolfers, and Eric Zitzewitz. All rights reserved. Short sections of text, not to exceed two paragraphs, may be quoted without explicit permission provided that full credit, including $(\odot$ notice, is given to the source. 
Partisan Impacts on the Economy: Evidence from Prediction Markets and Close Elections Erik Snowberg, Justin Wolfers, and Eric Zitzewitz

NBER Working Paper No. 12073

March 2006, Revised October 2006

JEL No. D72,E3,E6,G13,G14,H6

\begin{abstract}
$\underline{\text { ABSTRACT }}$ that economic outcomes also influence elections. We sidestep these problems by analyzing movements during Election Day. Analyzing high frequency financial fluctuations following the release of flawed higher equity prices, interest rates and oil prices and a stronger dollar under a Bush presidency than contest. Prediction market based analyses of all Presidential elections since 1880 also reveal a similar pattern of partisan impacts, suggesting that electing a Republican President raises equity valuations by 23 percent, and that since Reagan, Republican Presidents have tended to raise bond yields.

Erik Snowberg

Graduate School of Business

518 Memorial Way

Stanford, CA 94305

snowberg_erik@gsb.stanford.edu

Justin Wolfers

Assistant Professor of Economics

Business and Public Policy Department

Wharton School, University of Pennsylvania

3620 Locust Walk

Room 1456 Steinberg-Deitrich Hall

Philadelphia, PA 19104-6372

and NBER

jwolfers@wharton.upenn.edu

Eric Zitzewitz

Graduate School of Business

Stanford University

518 Memorial Way

Stanford, CA 94305

ericz@stanford.edu
\end{abstract}

Analyses of the effects of election outcomes on the economy have been hampered by the problem in economic indicators caused by clearly exogenous changes in expectations about the likely winner exit poll data on Election Day 2004, and then during the vote count, we find that markets anticipated under Kerry. A similar Republican-Democrat differential was also observed for the 2000 Bush-Gore 


\section{Introduction}

Do election outcomes affect the macroeconomy? Theoretical predictions differ, as canonical rational-choice political science models predict policy convergence, ${ }^{1}$ while more recent models of citizen-candidates [Besley and Coate 1997], party factions [Roemer, 1999], and strategic extremism [Glaeser et. al. 2006] predict divergence. Empirical evidence is mixed, reflecting the difficulty of establishing robust stylized facts about actual economic outcomes from a small number of Presidential election cycles. $^{2}$

We sidestep this limitation by exploiting two recent financial market developments: the electronic trading of equity index and other futures while votes are being counted on Election Night ${ }^{3}$ and the emergence of a liquid prediction market tracking the election outcome. Our analysis also benefits from natural experiments created by flawed, but widely believed, exit poll data. In 2004, exit polls released around 3pm Eastern time predicted a Bush defeat, and the price of a security paying $\$ 10$ if he was reelected fell from $\$ 5.5$ to $\$ 3$. As votes were counted that evening, the same security rallied and reached $\$ 9.5$ by midnight. High-frequency data shows the value of financial assets closely tracking these changes in expectations, allowing us to make precise and unbiased inferences of the effect of Bush's reelection on many economic variables. Similar events occurred in 2000, although without a prediction market precisely tracking changes in beliefs.

We proceed by analyzing the 2004 election, comparing the results from our high-frequency analysis with a more traditional pre-election analysis of daily data. We find that Bush's reelection led to modest increases in equity prices, nominal and real interest rates, oil prices, and the dollar, and that the biases in a more traditional research design would be substantial. We then conduct a

\footnotetext{
1 These models start with Hotelling [1929] and Downs [1957] and include more recent models of probabilistic voting [Lindbeck and Weibull, 1987] and lobbying [Baron, 1994].

${ }^{2}$ Alesina, Roubini and Cohen [1997] document faster economic growth under Democratic administrations (particularly in the first half of an administration), although Democrats have governed during periods of lower inflation, casting doubt on the interpretation that these differences reflect differences in aggregate demand management.

${ }^{3}$ Overnight trading of equity index futures began on the Chicago Mercantile Exchange's Globex platform in 1993. Prior to 1984, U.S. equity and bond markets were closed on Election Day.
} 
similar analysis of the 2000 election, finding partisan effects consistent with our analysis of the 2004 election. Finally, we turn to a longer sample, analyzing event returns surrounding elections back to 1880 . We find a remarkably consistent pattern of election outcomes affecting financial markets. Although our finding that elections affect financial markets suggests that they also affect economic policies and welfare, we caution that we can only speak to the effects of the elections we analyze. Further, the effect of a candidate on a variable such as equity prices may differ from their effect on economic welfare.

Past work examining the correlation of financial markets and expectations about political outcomes has used lower-frequency, pre-election data. For instance, Herron [2000] found that in the days leading up to the 1992 British election changes in the odds of a Labour victory were correlated with changes in British stock indices, leading him to infer that the election of Labour would have caused stock prices to decline by $5 \%-11 \%$. However, this correlation may instead reflect changing expectations about the economy driving changing expectations about the re-election of the incumbent. Knight [2006] sought to identify a causal effect by examining whether the difference in returns between "Pro-Bush" and "Pro-Gore" stock portfolios were correlated with the probability of Bush winning the 2000 election. This approach is less likely to be affected by reverse-causality, since an improvement in the economic outlook for a particular group of companies (e.g., defense) is unlikely to increase the re-election chances of an incumbent. Even so, the identification of partisan effects in this setting relies on the absence of unobserved factors affecting both the pricing of these portfolios and re-election prospects, and this might be questionable. ${ }^{4}$ Moreover, by design, this empirical strategy cannot speak to the effects of alternative candidates on aggregates.

\footnotetext{
${ }^{4}$ For instance, suppose that an election features a pro- and anti- war candidate, and the pro-war candidate is a more capable war President. If shares in defense contractors increase in value when the pro-war candidate's electoral prospects improve, one might be tempted to conclude that the defense contractor's stocks are worth more because there is a higher chance of the pro-war candidate will be elected. However a third factor-such as threatening actions from a another nation - may have led both numbers to appreciate: the defense contractor's from their increased sales in an increasingly likely war, and the pro-war candidate's from his country's increased need of his leadership in wartime.
} 


\section{The 2004 Election}

During the 2004 election cycle, TradeSports.com created a contract that would pay $\$ 10$ if

Bush were elected President, and zero otherwise. The price of this security yields a market-based estimate of the probability that Bush will win the election. ${ }^{5}$ We collected these Tradesports data on the last trade and bid-ask spread every 10 minutes during Election Day until the winner was determined in the early hours of the following morning. We pair these data with the price of the last transaction in the same 10 minute period for the December 2004 futures contract of various financial variables: the Chicago Mercantile Exchange (CME) S\&P 500 and Nasdaq 100 futures, CME currency futures, the Chicago Board Of Trade (CBOT) Dow Jones Industrial Average and 2 and 10 year Treasury Note futures, and a series of New York Mercantile Exchange (NYMEX) Light Crude Oil futures. ${ }^{6}$ The precision of our estimates is enhanced by the low volatility in overnight financial markets, ${ }^{7}$ the dearth of non-election financial news on Election Night, ${ }^{8}$ and the substantial trading volume generated on the Tradesports political prediction markets. ${ }^{9}$

Figure 1 shows the prediction market assessment of the probability of Bush's re-election and the value of the S\&P 500 future through our sample (noon EST on November $2^{\text {nd }}$ through to 6am, November $3^{\text {rd }}$, 2004). The prices track each other quite closely. The probability of Bush winning the election starts near 55 percent. When the exit poll data was leaked, the markets quickly incorporated

\footnotetext{
${ }^{5}$ Wolfers and Zitzewitz [2006] show that for realistic parameters regarding the risk aversion of traders, prediction market prices can be interpreted as a measure of the central tendency of beliefs about the probability of an event.

${ }^{6} \mathrm{We}$ analyze futures rather than the actual indices because only the futures are actively traded in the period after regular trading hours. The need to analyze data after the main U.S. markets closed also constrains the set of financial variables we can analyze.

${ }^{7}$ For example, in the fourth quarter of 2004, the standard deviation of 30-minute changes in the CME S\&P 500 futures from $4 \mathrm{pm}$ to $3 \mathrm{am}$ the following morning was 7.8 basis points, compared with 28.3 basis points during regular trading hours. While volatility was slightly higher on Election Night (the standard deviation of 30-minute changes was 10.2 basis points), the R-squared in our 30-minute-difference regressions of 0.33 suggests this increased volatility was explained by news about the Presidential election.

${ }^{8}$ Counts of the number of earnings announcements recorded by $\mathrm{I} / \mathrm{B} / \mathrm{E} / \mathrm{S}$ and news stories on the Dow Jones Newswire that did not include the words "Bush" or "Kerry" revealed that these measures were 39 and 23 percent lower on Election Day than their average on the two prior and two subsequent Tuesdays.

${ }^{9}$ On Election Day and the early hours of the following day, over $\$ 3.5$ million was transacted in contracts predicting either a Bush or Kerry victory, in 13,366 separate trades. The average bid-ask spread was $0.5 \%$ of the expiry value of a binary option. In contrast, for the Iowa Electronic Market on the winner of the popular vote in 2000 (there was no prediction market security on the Electoral College winner), election day volume totaled less than $\$ 20,000$.
} 
this information, sending Bush's probability of election to 30 percent and stocks down nearly one percent. When it became clear that the earlier exit poll data was faulty, Bush's chances rose to 95 percent and stocks rebounded, rising 11/2 percent. In both cases, it appears that the political news was reflected in the stock market slightly before the prediction market, mirroring what we found about Iraq War-related news in Wolfers and Zitzewitz [2005].

Figure 1 strongly suggests that equities were more valuable under a Bush Presidency than if Kerry had been elected. In order to get a precise estimate of just how much higher, we can regress changes in the S\&P 500 on changes in Bush's chances of re-election. Specifically, we estimate: ${ }^{10}$

$\Delta$ Log $\left(\right.$ Financial variable $\left._{t}\right)=\alpha+\beta \Delta$ Re-election probability $_{t}+\varepsilon_{t}$

Whereas all 10-minute intervals contain at least one prediction market trade, there are some intervals with no fresh trade in at least one of the financial markets. In these cases we analyze longer differences, weighting observations by the inverse of the number of periods the difference spans so as to correct for heteroskedasticity arising from unequal period lengths.

The timing of market movements in Figure 1 suggests that the timing of incorporation of information into prices may be different in equity and prediction markets. To allow for this possibility, we also estimate a version of the above model that uses 30-minute differences. Alternative specifications, such as 60-minute differences and Scholes-Williams [1977] regressions, yield coefficients of similar magnitude to the 30-minute differences.

Table 1 shows the result of regressions analyzing changes in a number of different financial prices. The coefficients can be interpreted as the percentage point difference in that indicator resulting from a Bush presidency instead of a Kerry Presidency. ${ }^{11}$

\footnotetext{
${ }^{10}$ See Wolfers and Zitzewitz [2005] for a small model clarifying the assumptions under which this estimating equation reveals the structural parameters of interest.

${ }^{11}$ Since our first natural experiment occurred while polls were still open, it is possible that there was a feedback whereby news of the exit polls or market movements led to changes in voting behavior. If both prediction and financial market traders were aware of this possibility — or if neither were aware — then our regression yields unbiased estimates. On the other hand, if the prediction markets over (under-)shot the change in probability of Bush's election relative to the financial market, then our regression will yield under (over-)estimates. Two robustness checks suggest that this is not an
} 
The results for the S\&P 500 suggest a precisely estimated effect, with the Bush presidency

yielding equity prices that are $1 \frac{1}{2}$ to 2 percent higher; other stock indices yield similar estimates. ${ }^{12,13}$

Of course, the equity market effects could reflect expectations of stronger output growth, or of

policy changes that are expected to favor returns to equity holders over debt holders, current over

future taxpayers, capital over labor, or current firms over potential entrants.

Some further insight into expected effects on output and inflation can be gained by

examining real and nominal bond yields and the dollar. The regressions in Table 1 suggest that 10-

year bond yields would be 11-12 basis points higher and 2-year bond yields 10-11 basis points

higher under a Bush administration. Ideally one would like to separate the effect of changes in

expected inflation from changes in expected real interest rates. While there was no overnight

trading in inflation-protected Treasury bills, we do observe the value of a closely related asset-the

iShares Lehman TIPS exchange traded fund (“TIP")—_at 3 pm, 4 pm, and 9:30 am the next morning.

Table 2 displays the percent change in prices between these inflation-indexed assets and

three comparison non-indexed assets: the 10 and 2-year CBOT Treasury futures, and the closest-

maturity non-TIP Treasury fund, the iShares Lehman 7-10 Year Treasury ("IEF"). ${ }^{14,15}$ The

12 percentage point decline in Bush's reelection probability from 3 to 4 pm was accompanied by a

important issue. First, we examined exit poll data and found no evidence that differences between voting patterns in the morning, early afternoon and evening varied across time zones, despite greater exposure to the "news" of a Kerry victory in the west. This suggests that this news did not change voter behavior. Second, long-differences which are not identified from the variation due to the faulty exit poll reporting (e.g. analyzing changes from $1 \mathrm{pm}$ on election day until $1 \mathrm{am}$ the next morning) yield results consistent with our main estimates.

${ }^{12} \mathrm{We}$ also obtain similar results when we split the sample at 8pm EST (when the second natural experiment began) or $10 \mathrm{pm}$ EST (when polls closed in all swing states), finding no significant differences in the coefficients during the two periods. This gives us confidence that our first experiment is not biased and that it is appropriate to combine the two experiments. (Indeed, comparing the outcomes across these two experiments can be thought of as an overidentification test).

${ }^{13}$ Our results are also robust to adding controls for the probability of Republican control of the House or Senate changing (by including the prices of the relevant Tradesports contracts as additional regressors). This robustness is likely due to these probabilities varying little on Election Day - the probability of a Republican House and Senate varied between 90 and 95 and between 82 and 88 percent, respectively, before rising toward 100 late in the evening. Our results are also robust to adding a control for the expected margin of victory, measured using Tradesports contracts on electoral college vote totals.

${ }^{14}$ We use the last trade before $3 \mathrm{pm}$, the last trade before $4 \mathrm{pm}$, and the first trade after 9:30am, respectively. Results are qualitatively similar if we take a quantity-weighted average of trades in the surrounding 10 minute period.

${ }^{15}$ The duration of the holdings of "TIP" and "IEF" is 5.9 and 6.6 years respectively, as calculated by Morningstar as of December 2004. 
one or two basis point reduction in both nominal and real bond yields, while the 55 percentage point increase from $4 \mathrm{pm}$ to 9:30 am the next morning was accompanied by a six to eight basis point increase in both real and nominal yields. Wald [1940] estimators constructed using these two windows yield results that are similar to our regressions in Table 1 for the bond futures, and suggest that the partisan effect on nominal bond yields was almost entirely due to changes in real interest rates, not expected inflation.

Coupled with the strengthening of the dollar under Bush, this suggests that the move in interest rates reflected expectations of expansionary fiscal policies, rather than an increased risk of inflation or default. Our estimate that Bush's reelection raised December 2004 and 2005 crude oil prices by between $\$ 0.60$ and $\$ 1.60$ per barrel is also consistent with expectations of higher demand for oil due to economic expansion. ${ }^{16}$

Our Election-Night natural experiment yields different results from the pure time series methods previously employed in the literature. Table 3 reports regressions explaining changes in daily closing prices of various financial variables using changes in the $4 \mathrm{pm}$ price of the Bush reelection contract, over a sample running from the start of prediction market trading in June 2003 to October 31, 2004. As above, we analyze longer differences to allow for slow incorporation of information into the Bush reelection contract, which traded less liquidly during the 17 months leading up to Election Night (total volume during these months was about \$11.4 million, about half of which was concentrated in September and October 2004). The observed relationship between election and economic expectations through this period likely confounds the effects of politics on the economy with the effects of economic conditions on the election.

The estimated "effect" of Bush's reelection on the stock market in this analysis is roughly a factor of ten larger than in Table 1. This suggests the bias in a naïve time series analysis is large,

\footnotetext{
${ }^{16}$ Oil prices might also be expected to be higher under Bush due to reduced conservation or reduced supply, but these explanations appear inconsistent with the term structure of the effect and with the candidates' positions on encouraging exploration.
} 
and that much of the correlation between equity markets and Bush's re-election probability in preelection data reflects reverse causation (e.g., higher stock prices help Bush) or third-factor causation (e.g., a stronger economy helps both Bush and the stockmarket).

For oil prices, these biases appear to cause a sign reversal. While Table 1 showed that Bush's re-election was expected to lead to higher oil prices, the results in Table 3 also reflect the reverse channel, whereby lower oil prices helped Bush's reelection chances. This reverse channel appears to be the dominant source of variation in the pre-election data, producing the negative correlation. The contrasting estimates in Tables 1 and 3 highlight the inadequacies of estimates of partisan effects that simply reflect the correlation between economic and electoral conditions.

Given that the results in Tables 1 and 2 reflect the effects of Bush on the economy, while those in Table 3 reflect both the effects of Bush on the economy and the effects of the economy on Bush, it seems reasonable to infer that we can combine these analyses to learn something about the effect of the economy on Bush's chances of re-election. We start by noting the following structural equations:

$$
\begin{aligned}
& \Delta \log \left(\text { Financial variable }_{t}\right)=\beta \Delta \text { Re-election probability } \text { v }_{t}+\varepsilon_{t} \\
& \Delta \text { Re-election probability }_{t}=\gamma \Delta \log \left(\text { Financial variable }_{t}\right)+\eta_{t} \\
& \mathcal{E}_{t} \sim D\left(0, \sigma_{\varepsilon}^{2}\right) ; \quad \eta_{t} \sim D\left(0, \sigma_{\eta}^{2}\right) ; E\left[\varepsilon_{t} \eta_{t}\right]=\rho_{\eta \bar{\varepsilon}} \sigma_{\bar{\varepsilon}} \sigma_{\eta}
\end{aligned}
$$

Note that this system involves five unknowns $\left(\beta, \gamma, \sigma_{\varepsilon}^{2}, \sigma_{\eta}^{2}\right.$ and $\left.\rho_{\eta \varepsilon}\right)$ while we observe only three relevant moments (the variance of the financial variable and the re-election probability, and their covariance). Separately, our analysis of Election-Day shocks gives us an estimate of $\beta$, implying that only one further assumption (about the correlation between the two structural shocks, $\left.\rho_{\eta \varepsilon}\right)$ is required to recover estimates of the effect of the economy on Bush's re-election prospects $(\gamma)$. To show the relevant intuition, if we estimate equation (2) by OLS, we obtain: 


$$
\gamma_{O L S}=v \gamma+(1-v) \beta^{1} \text { where } v=\frac{\sigma_{\varepsilon_{t}}^{2}+\beta \rho_{\varepsilon_{t} \eta_{t}} \sigma_{\varepsilon_{t}} \sigma_{\eta_{t}}}{\sigma_{\varepsilon_{t}}^{2}+2 \beta \rho_{\varepsilon_{\eta_{t}}} \sigma_{\varepsilon_{t}} \sigma_{\eta_{t}}+\beta^{2} \sigma_{\eta_{t}}^{2}}
$$

We can gain some intuition about the magnitude of $v$ by noting that it can be roughly interpreted as the share of financial market movements due to non-political factors. Specifically, since we know from Table 1 that $\beta$ is small, and hence if the correlation between the political and economic shocks $\left(\rho_{\eta \varepsilon}\right)$ is also small then $v$ will be close to one, suggesting that the OLS estimate of the effects of shocks to the economy on Bush's re-election probability will suffer only a small bias.

Running an OLS regression to estimate [2] using daily first differences (exactly as the first row of Table 3, except with independent and dependent variables reversed) yields:

$$
\Delta \text { Re-election probability } y_{t}=\begin{array}{ccl}
0.233 \Delta \log \left(S \& P 500_{t}\right)-0.0004 & (.0007) & \text { Adj. } R^{2}=0.017 \\
(.083) & n=321
\end{array}
$$

While statistically significant, these estimated effects seem rather small relative to the larger magnitudes found in the economic voting literature. Equally, OLS estimates of the effect of elections on the economy get larger as the election approaches. Reliably statistically significant results are only obtained in the two quarters leading up to the election, potentially providing some support for the finding in Fair [1978] that economic factors are particularly relevant for electoral outcomes when election day is nearer. ${ }^{17}$

That said, it seems plausible that political and economic shocks may be strongly correlated. If the correlation between the shocks is non-negative (for example when good news about foreign affairs causes rallies in both the stockmarket and Bush's re-election prospects), then the OLS regression provides a useful upper bound, as the true causal effect of economic conditions, $\gamma$, will lie below our reported $\gamma_{\text {OLS }}$.

\footnotetext{
${ }^{17}$ Ideally to determine the effect of the economy on electoral outcomes we would rely on an instrumental variables strategy that isolated economic shocks that did not also change the political environment directly. We have considered and discarded many such possible instruments, and leave this as an open question for future research.
} 


\section{Bush versus Gore}

Our analysis of the 2004 election in Table 1 alone does not allow us to disentangle whether the estimated effects are due to the election of a Republican (and hence reflect partisan effects), or the re-election of a sitting president (reflecting the benefits of stability). As such, we would like to be able to repeat this analysis for the 2000 election, in which there was no incumbent candidate running, and the Democrats were the incumbent party. Figure 2 illustrates that there were sharp movements in major financial indicators during the vote count, and these appear to coincide sharp shocks to assessments of the probability of Bush or Gore winning.

Unfortunately, we do not have an accurate estimate of the probability of victory of either candidate since there were no contracts that tracked this. The Iowa Electronic markets only tracked the anticipated popular vote share of each candidate, and the probability that each candidate would win a plurality of the popular vote. Since the winner of the popular vote (Gore) did not win the election, and it was quite clear early on Election Night that this was likely, the Iowa market price cannot be used as an estimate of the probability that a given candidate would win the election. Centrebet, an Australian bookmaker, did trade an appropriate contract, but closed their market on the morning of the election. Their election-morning odds suggested that Bush had a $60 \%$ chance of winning the election. We can use this number to bound the effect of Bush versus Gore on economic indicators.

If we assume that the prices of the various indicators at the beginning of our sample period correspond to a $60 \%$ chance of Bush winning, then the decline observed between $6 \mathrm{pm}$ and $9 \mathrm{pm}$ cannot represent more than a $60 \%$ decrease in the chance of a Bush victory. Likewise, the change from 9 pm to 2:15am cannot represent more than a 100\% increase in the probability of a Bush win. From this, Table 4 infers bounds on the relevant Wald Estimators of the effect of Bush versus Gore, finding that a Bush presidency caused at least a $1 \frac{1}{2} \%$ increase in the S\&P 500, a $3 \frac{1}{2} \%$ increase in the Nasdaq 100 and a $1 \frac{1}{2} \%$ appreciation of the dollar versus a trade weighted currency portfolio. The 
estimates from these two experiments in 2000 are consistent both with each other and with the effects observed over the two analogous experiments in 2004, suggesting that our estimates are isolating partisan effects rather than the costs of transferring from an incumbent regime to a new one.

\section{A Century of Elections}

Because the 2000 and 2004 elections are the only two close elections since overnight trading began, we cannot replicate the above analysis for earlier elections. However, we can perform a more traditional event study, comparing aggregate returns from the pre-election close to the postelection close (the narrowest event window possible given that historically equity markets were closed on Election Day). Naturally the identifying assumption in this case-that markets are responding to election returns rather than other news-is more tenuous over this longer event window. (This is an important reason that our estimates from this analysis will be less precise.)

Santa-Clara and Valkanov [2003] have previously compared event returns accompanying Democratic and Republican victories, finding no consistent pattern. However, as Shelton [2005] has emphasized, it is important to distinguish elections which transmit essentially no news (such as a market rally coinciding with Clinton's widely expected re-election in 1996) from elections involving large shocks (Truman surprisingly beating Dewey in 1948). Thus we once again turn to prediction markets in order to highlight the relationship between equity market movements and electoral surprises. Data on election betting back to 1880 were pieced together from a variety of sources. Paul Rhode and Koleman Strumpf were particularly helpful, providing results from the "Curb Market" - a large scale political market that operated on the curb of Wall Street through most of this period. This market is probably best described as an historical open-outcry version of the modern Tradesports markets, and is described in Rhode and Strumpf [2004, 2005]. These data were supplemented with alternative sources for recent decades, including British and Australian 
bookmakers, the Iowa Electronic Markets, and Tradesports. ${ }^{18}$ Combining these prediction market data with election outcomes yields a simple measure of the resulting partisan shock: ${ }^{19}$

Partisan Shock $_{t}=I\left(\right.$ Republican President elected $\left._{t}\right)-$ Probability of a Republican president P $_{t-1}$.

In order to compile a long-run series of daily stock returns, we analyze movements in

Schwert's [1990] daily equity returns data (which attempts to replicate returns on a value-weighted total return index) supplemented by returns on the CRSP-value-weighted portfolio since 1962, and data from Kalinke [2004] prior to 1888.

Figure 3 shows that historically equity markets have risen when Republican presidents have been elected, and the larger the surprise, the more they rise. This is in apparent conflict with SantaClara and Valkanov [2003], who find no systematic relationship, albeit between equity returns and the sign of the electoral surprise (i.e., whether a Republican is elected).

Table 5 attempts to reconcile these two results, initially analyzing relationship between return and sign for Santa-Clara and Valkanov's 1928-1996 sample. As with their analysis, we find a positive, but insignificant, relationship when only analyzing whether the Republican Party wins the election. If instead we exploit our prediction market data to account for the magnitude of the electoral surprise, our results are clearly significant, and they are slightly more so when we expand to the full 1880 to 2004 time period for which we can obtain the needed data. A final specification jointly analyzes both our variable describing the partisan shock (measured as the change in beliefs that a Republican would be elected) and the change in expectations that the incumbent party would be re-elected, again finding strong evidence that partisanship, rather than incumbency effects are driving our results. ${ }^{20}$

\footnotetext{
${ }^{18}$ See the Appendix for details on the construction of these prediction market data.

19 This measure of the partisan shock revealed by the vote count is valid only if the election winner is known by the end of the event window. We have checked press reports of each election, and this assumption is only potentially problematic for the 1916 and 2000 elections. Dropping these elections from the regressions in Table 5 yields slightly stronger results.

${ }^{20}$ There are many ways to define incumbency from incumbent parties to the incumbency of a particular candidate. We tested several specifications along this spectrum and found all yielded similar conclusions. We also allowed the
} 
Thus, this analysis finds further evidence of statistically and economically significant partisan effects on equity markets, and robustness checking suggests that these estimates are not driven by specific outliers. ${ }^{21}$ Moreover, the estimated magnitude is remarkably similar to our assessments based on intra-day movements in the 2000 and 2004 elections, with the election of a Republican president calculated to have typically been associated with a 2-3 percent rise in equity prices. The statistical power of our election-night approach is illustrated by the relative precision of the estimates in Tables 1 and Table 5: our estimate of partisan effects from a single night $(11 / 2 / 2004)$ yielded standard errors one-half as large those on our estimate using daily data from the last 124 years of Presidential elections, reflecting the fact that over a ten-minute period there are fewer unrelated shocks to financial markets creating noise. Equally, the analysis of historical data is also likely shaped by the fact that there is heterogeneity in the ideology and quality of the specific Republican candidates, and this heterogeneity is not present in the single-election case studies.

Figure 4 turns to bond yields showing that they were historically quite unresponsive to political shocks until the election of Reagan in 1980 when the yield on the 10-year Treasury bill increased 15 basis points. Prediction markets viewed the chances of his election at $80 \%$. Regressing changes in bond yields on the change in probability of a Republican president as in Table 5 reveals that there was no statistically or economically significant difference in the reaction of bond markets to Democratic or Republican candidates from 1920 to 1976. From 1980 onward a Republican President increased the 10 -year bill yield 13 basis points $(\mathrm{p}=0.15)$. Although we have few observations, this pattern is consistent with both the relatively low national debt before 1980 and a re-alignment of the political parties with regard to government debt after 1980.

incumbency effect to vary with the incumbent's performance, interacting the incumbency effect with various measures of economic performance, and again found evidence of partisan but not incumbency or performance effects.

${ }^{21} \mathrm{We}$ are unable to test the effect of party in control of congress since this would require knowledge of the market's assessment of the probability of a change in congressional control. Prediction markets did not track this before 1994. If we assume that a certain proportion of seats going into an election would give a party near certainty of maintaining congressional control we can test whether a President winning with control of Congress creates different returns then winning without. We varied the necessary margin of control from 0.5 to 0.72 in increments of 0.01 and found that at no level was there a statistically significant effect of winning with control of Congress versus winning without. 


\section{Discussion}

Large natural experiments caused by flawed election-evening psephology yielded large and plausibly exogenous shocks to the perceived probability of Bush winning both the 2000 and 2004 elections, enabling us to estimate the causal effect of alternative Presidential candidates on various financial indices.

Our estimates are informative for various questions in the political economy literature. Specifically, partisan political business-cycle models specify that parties have different intrinsic policy goals. An immediate implication of these theories is that changes in election probabilities generate shocks to expectations about macroeconomic policy, and indeed we find that changes in the perceived probability of electing a Republican President caused changes in expected bond yields, equity and oil prices. A closer inspection of our results yielded somewhat more surprising insights. The finding that equity values were expected to be 2-3 percent higher under Bush are easily reconciled with expectations of favored treatment of capital over labor, current firms over future entrants, equity over bond holders, or expectations of stronger real activity. Long bond yields were expected to be 10 to 12 basis points higher under Bush, a finding at odds with the usual characterization of right-wing parties as more strongly committed to balancing the budget, even if the cost is lower economic activity. That said, this finding is consistent with observed higher deficits under Republicans since the 1980s. Finally, while the literature so far has focused on election outcomes as generating monetary or fiscal shocks, our oil price results suggest that macroeconomic "supply shocks" might also reflect partisan preferences.

An older strand of the literature claims that candidates and parties will converge to the same policy - that of the median voter. Under this view, changing policies reflect changing preferences of voters, rather than changes in the officeholder, and disentangling the two makes falsification of the theory all the more difficult. Our analysis suggests that financial markets do not believe that 
policy convergence occurs. While Jayachandran [2006] and Knight [2006] have shown evidence of partisanship affecting particular groups of firms differentially, our data speak to broader macroeconomic effects.

The reason that we have emphasized the importance of analyzing the effects of exogenous shocks to the probability of re-election is that under retrospective economic voting a simple time series regression of financial prices on re-election probabilities will confound the causal effects of an incumbent's policies on financial markets with the effects of expectations about the economy changing expectations about the incumbent's re-election prospects. Our natural experiments allow us to isolate the former, and the fact that this yields substantially different results from the longer time series points to the importance of the economic voting channel highlighted by Fair [1978].

Our results are contrary to the findings of Santa-Clara and Valkanov [2003] who find no sharp changes on Election Day, but large excess returns under Democratic administrations. The greater statistical power of our approach resolves our differences regarding the former observation, while reconciliations of the latter include the possibility that: 1) Past Democratic Presidents pursued policies that were more beneficial for equity returns, but investors have not noticed; 2) Past Democratic Presidents have pursued beneficial policies, but investors do not expect future ones to do so; and 3) Partisan effects are small relative to the variance of equity returns during a Presidential term, and past Democratic Presidents have simply been lucky in this regard.

Finally, our results speak directly to the question asked by Jones and Olken [2005] as to whether leaders matter. Those authors also emphasize the fact that a country's leaders both determine and are determined by their economic performance and hence analyze the effects of clearly exogenous shocks caused by unexpected leader deaths, finding large effects on growth. Similarly, Fisman [2001] analyzes financial market implications of shocks to President Suharto's health. Our approach is similar in that we analyze the effects of unexpected changes to beliefs about election outcomes. 
While our results are informative in a wide variety of settings, it is also important to point out their shortcomings. In that we limit ourselves to U.S. Presidential elections, our analysis has sacrificed generality for precision. Our observations reflect changing expectations among financial market traders, rather than actual partisan differences; the partisan differences we estimate for 2000 and 2004 reflect the particularities of Bush versus Gore or Kerry rather than the more general leanings of the Democratic or Republican parties; and the complexity of the platforms of Kerry and Bush do not permit us to draw strong conclusions about which policies lead to the effects we observe. 


\section{References}

Alesina, Alberto, Nouriel Roubini and Gerald D. Cohen, Political Cycles and the Macroeconomy (Cambridge, MA: The MIT Press, 1997).

Baron, David P., "Electoral Competition with Informed and Uninformed Voters," The American Political Science Review, LXXXVIII (1994), 33-47.

Besley, Timothy and Stephen Coate, "An Economic Model of Representative Democracy," The Quarterly Journal of Economics, CXII (1997), 85-114.

Cutler, David M., "Tax Reform and the Stock Market: An Asset Price Approach," The American Economic Review, LXXVII (1988), 1107-1117.

Downs, Anthony, An Economic Theory of Democracy. (New York, NY: Harper Collins, 1957).

Fair, Ray, "The Effect of Economic Events on Votes for President," The Review of Economics and Statistics, LX (1978), 159-173.

Fisman, Raymond, 2001, "Estimating the Value of Political Connections," The American Economic Review, XCI (2001), 1095-1102.

Glaeser, Edward L., Giacomo A. M. Ponzetto and Jesse M. Shapiro, "Strategic Extremism: Why Republicans and Democrats Divide on Religious Values," The Quarterly Journal of Economics, CXX (2006), 1283-1330.

Herron, Michael, "Estimating the Economic Impact of Political Party Competition in the 1992 British Election," American Journal of Political Science, XLIV (2000), 326-337.

Hotelling, Harold, 1929, “Stability in competition,” Economic Journal, XXXIX (1929), 41-57.

Jayachandran, Seema, “The Jeffords Effect,” Journal of Law and Economics, forthcoming (2006).

Jones, Benjamin and Benjamin Olken. 2005. "Do Leaders Matter? National Leadership and Growth Since World War II," The Quarterly Journal of Economics, CXX (2005), 835-864.

Kalinke, Tom H., Before Dow and Jones: Daily Stock Market Averages, 1855 Through 1896 (Madison WI: The $19^{\text {th }}$ Century Stock Price Project, 2004).

Knight, Brian, "Are Policy Platforms Capitalized Into Equity Prices: Evidence from Equity Markets During the Bush / Gore 2000 Presidential Election", Journal of Public Economics, forthcoming (2006).

Lindbeck, Assar and Jorgen Weibull, "Balanced Budget Redistribution as the Outcome of Political Competition,” Public Choice, LII (1987), 273-297.

Newey, Whitney K. and Kenneth D. West, "A Simple, Positive Semi-Definite, Heteroskedasticity and Autocorrelation Consistent Covariance Matrix," Econometrica, LV (1987), 703-708.

Rhode, Paul W. and Koleman S. Strumpf, "Historical Presidential Betting Markets," Journal of Economic Perspectives, XVIII (2004), 127-142.

and "Manipulation in Political Stock Markets", mimeo,

University of North Carolina (2005).

References - 1 
Roemer, John E., "The Democratic Political Economy of Progressive Income Taxation," Econometrica, LXVII (1999), 1-19.

Santa-Clara, Pedro and Rossen Valkanov, "The Presidential Puzzle: Political Cycles and the Stock Market," The Journal of Finance, LVIII (2003), 1841-1872.

Scholes, Myron and Joseph Williams, "Estimating Betas from Nonsynchronous Data," Journal of Financial Economics, V (1977), 309-327.

Shelton, Cameron, "Electoral Surprise and the Economy," mimeo, Stanford University (2005).

Schwert, G. William, “Indexes of U.S. stock prices from 1802-1987," Journal of Business, LXIII (1990), 399-327.

White, Halbert, "A Heteroskedasticity-Consistent Covariance Matrix Estimator and a Direct Test for Heteroskedasticity," Econometrica, XLVIII (1980), 817-838.

Wolfers, Justin and Eric Zitzewitz, "Using Markets to Inform Policy: The Case of the Iraq War," mimeo, University of Pennsylvania (2005). and NBER Working Paper\#12200 (2006). "Interpreting Prediction Market Prices as Probabilities," 
Table 1

Effects of Bush versus Kerry on Financial Variables

\begin{tabular}{|c|c|c|c|c|}
\hline \multirow[t]{2}{*}{ Dependent Variable } & \multicolumn{4}{|c|}{10 Minute First Differences 30 Minute First Differences } \\
\hline & $\begin{array}{l}\text { Estimated Effect of } \\
\text { Bush Presidency }\end{array}$ & $\mathbf{n}$ & $\begin{array}{c}\text { Estimated Effect of } \\
\text { Bush Presidency }\end{array}$ & $\mathbf{N}$ \\
\hline \multirow[b]{2}{*}{ S\&P 500} & \multicolumn{4}{|c|}{ Dependent Variable: $\Delta \log ($ Financial Index) } \\
\hline & $\begin{array}{l}0.015^{* * *} \\
(.004)\end{array}$ & 104 & $\begin{array}{l}0.021^{* * * * * * x} \\
(.005)\end{array}$ & 35 \\
\hline Dow Jones Industrial Average & $\begin{array}{l}0.014^{* * * *} \\
(.005)\end{array}$ & 84 & $\begin{array}{l}0.021^{* * * *} \\
(.006)\end{array}$ & 29 \\
\hline Nasdaq 100 & $\begin{array}{l}0.017^{* * *} \\
(.006)\end{array}$ & 104 & $\begin{array}{l}0.024^{* * *} \\
(.008)\end{array}$ & 35 \\
\hline \multirow[t]{2}{*}{$\begin{array}{l}\text { U.S. Dollar } \\
\text { (vs. Trade-weighted basket) }\end{array}$} & $\begin{array}{l}0.004 \\
(.003)\end{array}$ & 93 & $\begin{array}{l}0.005^{* *} \\
(.003)\end{array}$ & 34 \\
\hline & \multicolumn{4}{|c|}{ Dependent Variable: $\Delta$ Price } \\
\hline \multirow{4}{*}{$\begin{array}{l}\text { Light } \\
\text { Crude Oil } \\
\text { Futures }\end{array}$} & $\begin{array}{l}1.110^{* * *} \\
(.371)\end{array}$ & 88 & $\begin{array}{l}1.706^{* *} \\
(.659)\end{array}$ & 29 \\
\hline & $\begin{array}{l}0.652^{*} \\
(.375)\end{array}$ & 85 & $\begin{array}{l}1.020 \\
(.610)\end{array}$ & 28 \\
\hline & $\begin{array}{r}-0.580 \\
(.783)\end{array}$ & 63 & $\begin{array}{r}-0.666 \\
(.863)\end{array}$ & 21 \\
\hline & \multicolumn{4}{|c|}{ Dependent Variable: AYield } \\
\hline 2 Year T-Note Future & $\begin{array}{c}0.104^{*} \\
(.058)\end{array}$ & 84 & $\begin{array}{l}0.108^{* * * *} \\
(.036)\end{array}$ & 30 \\
\hline 10 Year T-Note Future & $\begin{array}{l}0.112^{* *} \\
(.050)\end{array}$ & 91 & $\begin{array}{l}0.120^{* *} \\
(.046)\end{array}$ & 31 \\
\hline
\end{tabular}

Notes: ${ }^{* * * *},{ }^{* * *},{ }^{*}$ denote statistically significant at $1 \%, 5 \%$ and $10 \%$, respectively. (White [1980] standard errors in parentheses.) The sample period is noon Eastern Time on 11/2/2004 to six a.m. on 11/3/2004. Election probabilities are the most recent transaction prices collected every ten minutes from Tradesports.com. S\&P, Nasdaq, and foreign exchange futures are from the Chicago Mercantile Exchange; Dow and bond futures are from the Chicago Board of Trade, while oil futures data are from the New York Mercantile Exchange. Equity, bond and currency futures have December 2004 delivery dates. Yields are calculated for the Treasury futures using the daily yields reported by the Federal Reserve for 2 and 10-year Treasuries and projecting forward and backward from the bond market close at $3 \mathrm{pm}$ using future price changes and the future's durations of 1.96 and 7.97 reported by CBOT. The trade-weighted currency portfolio includes six currencies with CME-traded futures (the Euro, Yen, Pound, Australian and Canadian dollars, and the Swiss Franc). 
Table II

Changes in bond yields were unrelated to changes in inflation expectations

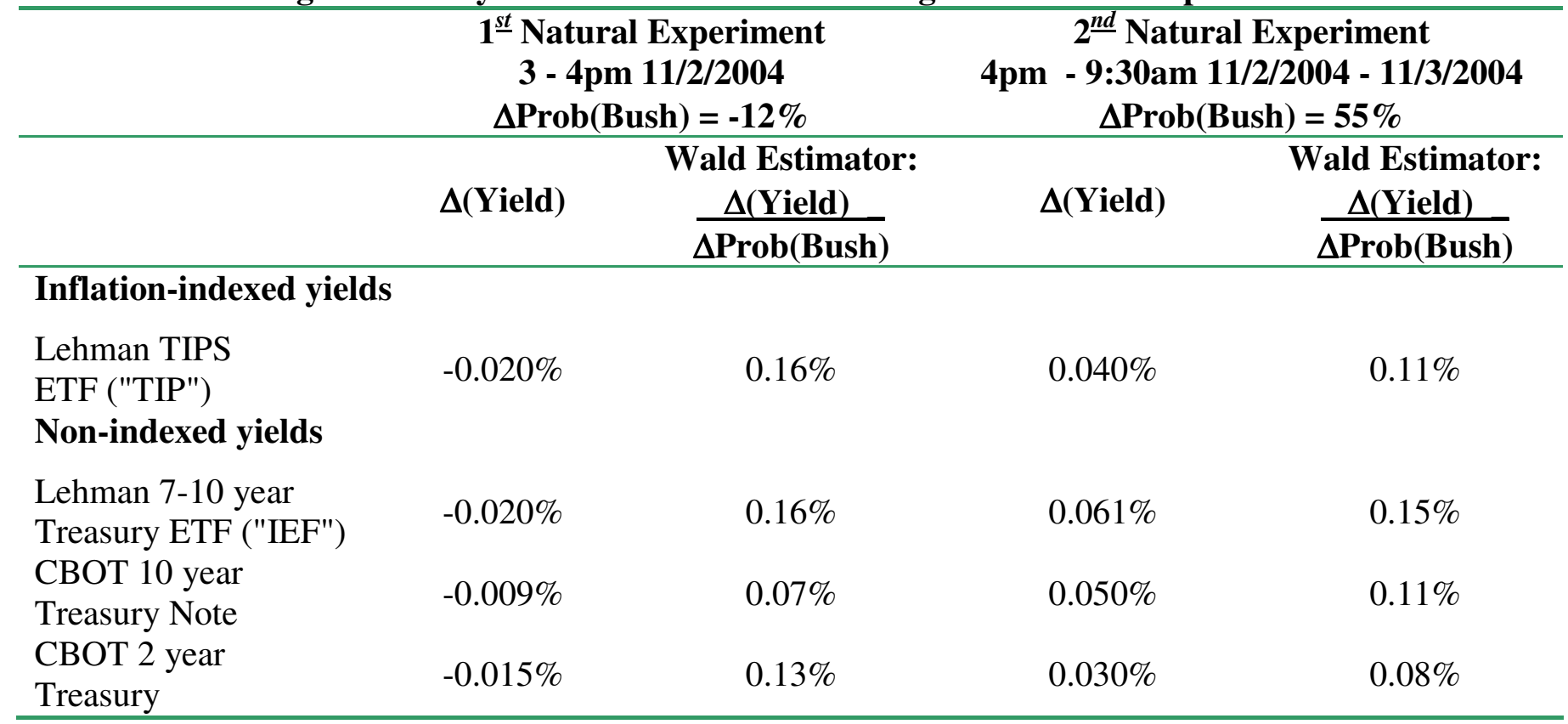

Notes: For the TIP and IEF exchange traded funds (ETF), the implied yield for 3 pm is taken to be the constant-maturity daily yield calculated by the Federal Reserve for TIPS and Treasuries with the closest maturity to average holdings of the ETFs ( 7 years in both cases). For the 10 and 2-year CBOT Treasury futures, the 10 and 2-year series are used. These yields are then projected forward using price changes and the average duration of the funds' holdings, as reported by Morningstar in December 2004.

Table III

Re-election Probabilities and Financial Variables Through the Campaign

\begin{tabular}{|c|c|c|c|c|c|c|}
\hline \multirow{2}{*}{$\begin{array}{l}\text { Independent Variable: } \\
\Delta \text { Bush election probability }\end{array}$} & \multicolumn{2}{|c|}{ Daily differences } & \multicolumn{2}{|c|}{ 5-day differences } & \multicolumn{2}{|c|}{ 20-day differences } \\
\hline & Estimate & $\mathbf{n}$ & Estimate & $\mathbf{n}$ & Estimate & $\mathbf{N}$ \\
\hline & \multicolumn{6}{|c|}{ Dependent Variable: $\Delta$ Log(Financial Index) } \\
\hline S\&P 500 & $\begin{array}{r}0.087^{* *} \\
(.034)\end{array}$ & 321 & $\begin{array}{r}0.128^{* *} \\
(.062)\end{array}$ & 317 & $\begin{array}{r}0.243^{* * * *} \\
(.065)\end{array}$ & 302 \\
\hline Dow Jones Industrial Average & $\begin{array}{r}0.093^{* * * *} \\
(.032)\end{array}$ & 321 & $\begin{array}{r}0.145^{* *} \\
(.061)\end{array}$ & 317 & $\begin{array}{r}0.275^{* * * *} \\
(.090)\end{array}$ & 302 \\
\hline Nasdaq 100 & $\begin{array}{r}0.143^{*} \\
(.062)\end{array}$ & 321 & $\begin{array}{r}0.212^{* *} \\
(.098)\end{array}$ & 317 & $\begin{array}{r}0.299^{* * * *} \\
(.108)\end{array}$ & 302 \\
\hline \multirow[t]{2}{*}{$\begin{array}{l}\text { U.S. Dollar } \\
\text { (vs. Trade-weighted basket) }\end{array}$} & $\begin{array}{r}0.040^{* *} \\
(.019)\end{array}$ & 321 & $\begin{array}{l}0.017 \\
(.022)\end{array}$ & 317 & $\begin{array}{r}-0.022 \\
(.047)\end{array}$ & 302 \\
\hline & \multicolumn{6}{|c|}{ Dependent Variable: $\Delta$ Price } \\
\hline \multirow[t]{2}{*}{$\begin{array}{l}\text { Light Crude Oil Futures } \\
\text { (Near month) }\end{array}$} & $\begin{array}{r}0.390 \\
(4.504)\end{array}$ & 318 & $\begin{array}{r}-7.221 \\
(7.188)\end{array}$ & 314 & $\begin{array}{r}-12.547^{*} \\
(6.793)\end{array}$ & 299 \\
\hline & \multicolumn{6}{|c|}{ Dependent Variable: AYield } \\
\hline 10 Year T-Bill Yield & $\begin{array}{r}1.130^{* * * * *} \\
(.373)\end{array}$ & 321 & $\begin{array}{l}0.463 \\
(.489)\end{array}$ & 317 & $\begin{array}{r}-0.028 \\
(.718)\end{array}$ & 302 \\
\hline
\end{tabular}

Notes: $^{* * * * * *},{ }^{*}$ denote statistically significant at $1 \%, 5 \%$ and $10 \%$, respectively. Newey-West [1987] standard errors in parentheses, allowing for autocorrelation over 1, 5 and 20 lags, respectively. Financial variables are daily closing prices. The U.S. dollar is measures relative to a trade-weighted basket of the same currencies as in Table 1. Sample covers all trading days from June 2003 to October 2004. 
Table IV

Natural Experiments in 2000 provide estimates in line with those from 2004.

\begin{tabular}{|c|c|c|c|c|}
\hline & \multicolumn{2}{|c|}{$\begin{array}{c}1^{\text {st }} \text { Natural Experiment } \\
6 \text { pm - 9pm 11/6/2000 } \\
0 \% \geq \Delta \text { Prob(Bush }) \geq-60 \%\end{array}$} & \multicolumn{2}{|c|}{$\begin{array}{c}2^{\frac{n d}{n}} \text { Natural Experiment } \\
\text { 9pm }-2: 15 \text { am 11/6/2000 }-11 / 7 / 2000 \\
0 \% \leq \Delta \text { Prob(Bush) } \leq 100 \%\end{array}$} \\
\hline & \multirow[t]{2}{*}{$\% \Delta$ (Price) } & $\begin{array}{c}\text { Wald Estimator: } \\
\% \Delta \text { (Price) }\end{array}$ & \multirow[t]{2}{*}{$\% \Delta$ (Price) } & $\begin{array}{c}\text { Wald Estimator: } \\
\% \Delta \text { (Price) }\end{array}$ \\
\hline & & $\Delta$ Prob(Bush) & & $\Delta$ Prob(Bush) \\
\hline S\&P 500 & $-0.9 \%$ & $\geq 1.4 \%$ & $1.6 \%$ & $\geq 1.6 \%$ \\
\hline Nasdaq 100 & $-2.3 \%$ & $\geq 3.8 \%$ & $3.5 \%$ & $\geq 3.5 \%$ \\
\hline $\begin{array}{l}\text { U.S. Dollar } \\
\text { (vs. Trade-weighted basket) }\end{array}$ & $-0.3 \%$ & $\geq 0.5 \%$ & $0.6 \%$ & $\geq 0.6 \%$ \\
\hline
\end{tabular}

Notes: Election Night events indicate that the highest probability of a Bush loss occurred around 9pm, and the highest probability of a Bush win occurred at 2:15 am the next morning. We made this determination based on the timeline found at:

http://www.pbs.org/newshour/media/election2000/election_night.html

Table V

The Effect of a Republican on Value-Weighted Equity Returns

Dependent Variable:

Stock returns from election-eve close to post-election

close

\begin{tabular}{|c|c|c|c|c|}
\hline I(GOP President) & 0.0129 & & & \\
\hline [As in Santa-Clara and Valkanov] & $(.0089)$ & & & \\
\hline$\Delta$ Prob(GOP President) & & $0.0297^{* *}$ & $0.0249^{* * *}$ & $0.0242^{* * *}$ \\
\hline (Prediction markets) & & $(.118)$ & $(.0082)$ & $(.0084)$ \\
\hline $\begin{array}{l}\text { AProb(Incumbent party elected) } \\
\text { (Prediction markets) }\end{array}$ & & & & $\begin{array}{r}-0.0038 \\
(.0085)\end{array}$ \\
\hline Constant & $\begin{array}{c}-0.0102 \\
(.0059)\end{array}$ & $\begin{array}{r}-0.0027 \\
(.0040)\end{array}$ & $\begin{array}{c}0.0014 \\
(.0028)\end{array}$ & $\begin{array}{l}0.0013 \\
(.0028)\end{array}$ \\
\hline Sample & $1928-1996$ & $1928-1996$ & $1880-2004$ & $1880-2004$ \\
\hline $\mathbf{N}$ & 18 & 18 & 32 & 32 \\
\hline
\end{tabular}




\section{Figure I}

The S\&P 500 is higher under a Bush versus Kerry presidency.

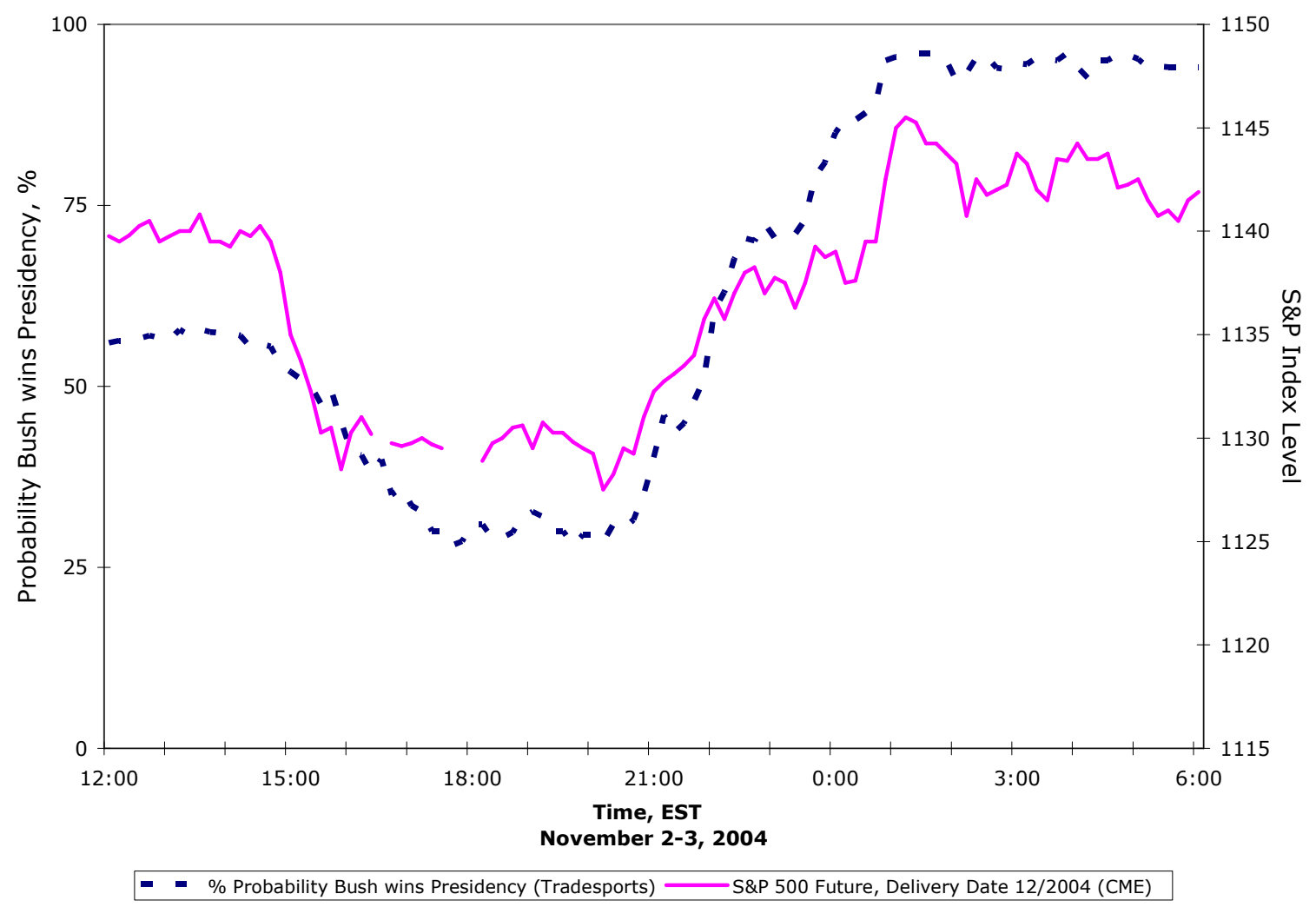

Figure II

Bush had similar effects on economic indicators compared to Kerry or Gore.

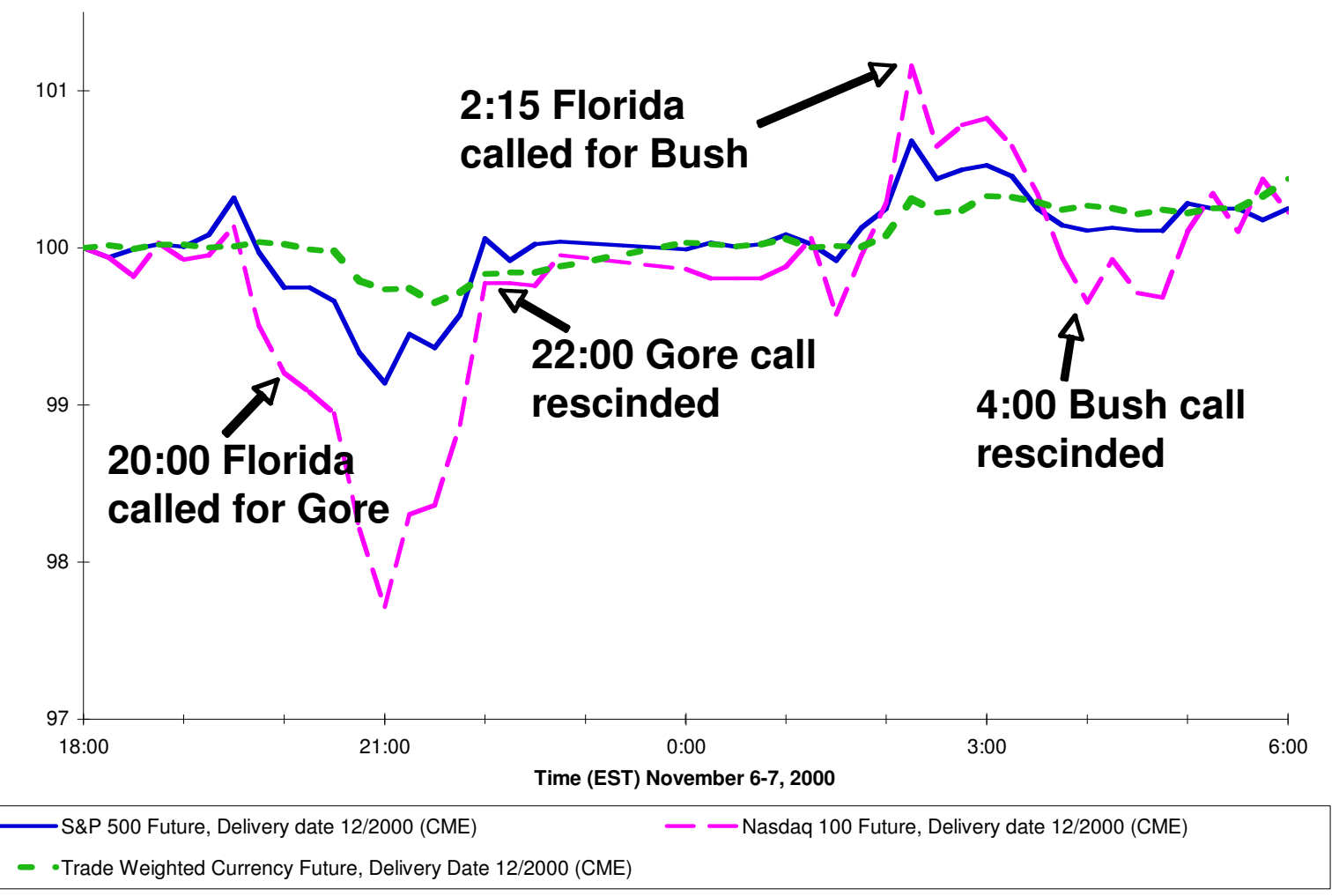

Notes: Timing of events are taken from: http://www.pbs.org/newshour/media/election2000/election_night.html

Figures - 4 


\section{Figure III}

\section{Equity markets have historically preferred Republican presidents.}

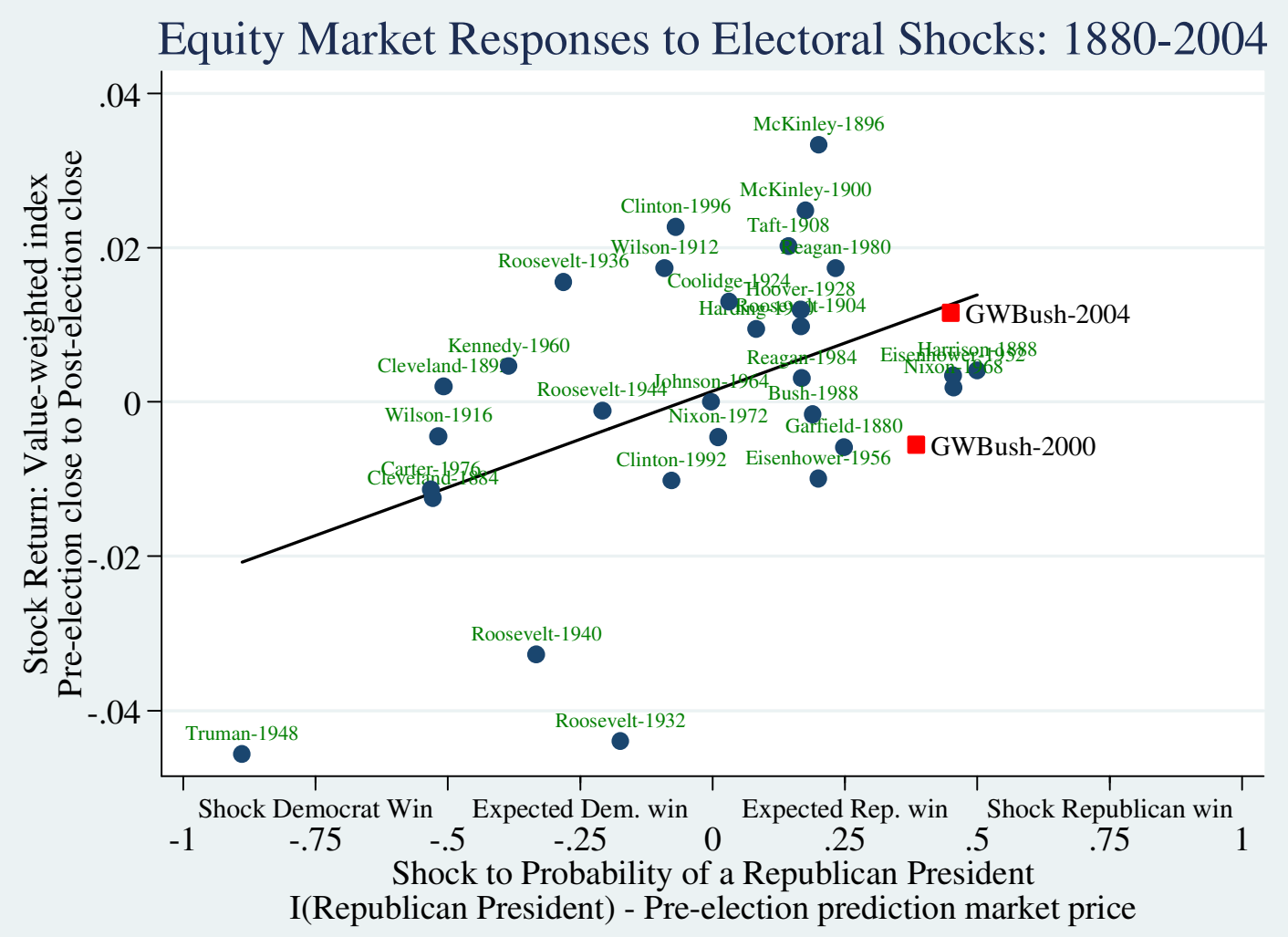

Figure IV

Bond markets before 1980 did not react to elections.

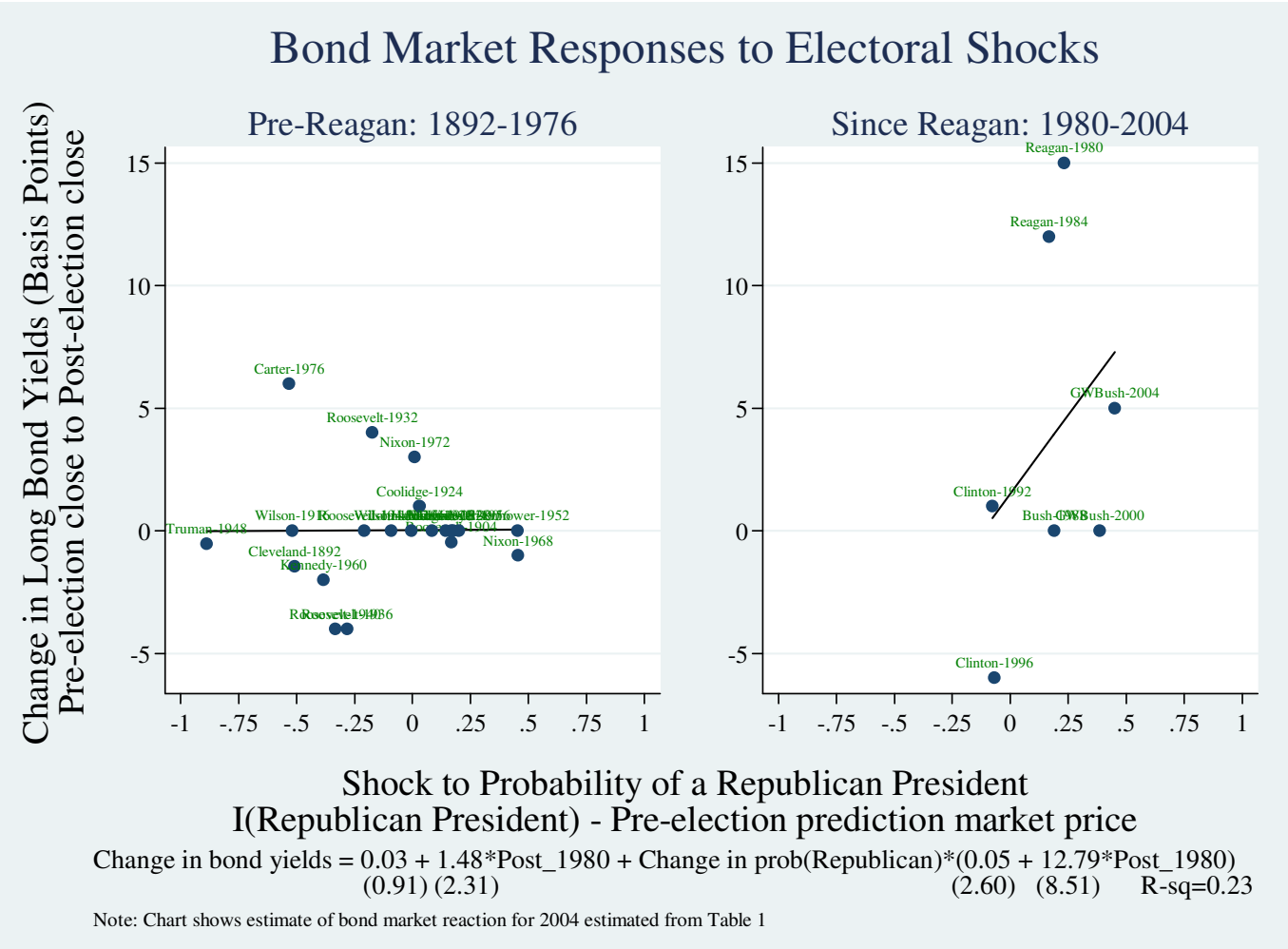

Figures - 5 
Appendix Table

Expected and Actual Election Results, 1880-2004.

\begin{tabular}{|c|c|c|c|c|c|c|c|c|c|}
\hline Year & $\begin{array}{l}\text { Democrat } \\
\text { candidate }\end{array}$ & $\begin{array}{l}\text { Republican } \\
\text { candidate }\end{array}$ & $\begin{array}{l}\text { Prediction } \\
\text { market: } \\
\text { Prob(GOP } \\
\text { Win) }\end{array}$ & $\begin{array}{l}\text { Gallup } \\
\text { poll: } \\
\text { Expected } \\
\text { GOP Vote } \\
\text { Share (2pp) }\end{array}$ & Winner & $\begin{array}{c}\text { GOP } \\
\text { Popular } \\
\text { Vote Share } \\
(2 \text { party } \\
\text { vote share) }\end{array}$ & $\begin{array}{c}\text { Partisan } \\
\text { Shock } \\
\text { I(GOP Pres) - } \\
\text { p(GOP Pres }) \text {. }\end{array}$ & $\begin{array}{c}\% \Delta \text { Stock } \\
(t-1 \text { to } t+1)\end{array}$ & $\begin{array}{l}\text { Regression } \\
\text { Residual } \\
\text { (Table 5, } \\
\text { col. 3) }\end{array}$ \\
\hline 1880 & Hancock & Garfield & $75.2 \%$ & n.a. & Garfield & $50.01 \%$ & $24.8 \%$ & $-0.59 \%$ & $-1.35 \%$ \\
\hline 1884 & Cleveland & Blaine & $52.8 \%$ & n.a. & Cleveland & $49.87 \%$ & $-52.8 \%$ & $-1.25 \%$ & $-0.07 \%$ \\
\hline 1888 & Cleveland & Harrison & $50.0 \%$ & n.a. & Harrison & $49.59 \%$ & $50.0 \%$ & $0.40 \%$ & $-0.98 \%$ \\
\hline 1900 & Bryan & McKinley & $82.4 \%$ & n.a. & McKinley & $53.17 \%$ & $17.6 \%$ & $2.48 \%$ & $1.90 \%$ \\
\hline 1904 & Parker & T. Roosevelt & $83.3 \%$ & n.a. & T. Roosevelt & $60.01 \%$ & $16.7 \%$ & $0.98 \%$ & $0.42 \%$ \\
\hline 1908 & Bryan & Taft & $85.7 \%$ & n.a. & Taft & $54.51 \%$ & $14.3 \%$ & $2.01 \%$ & $1.52 \%$ \\
\hline 1912 & Wilson & $\begin{array}{l}\text { T. Roosevelt (P) } \\
\text { / Taft (Rep.) }\end{array}$ & $\begin{array}{c}9.1 \% \\
\left(=p^{\text {Rep }}+p^{\text {Prog }}\right)\end{array}$ & n.a. & Wilson & $\begin{array}{c}39.56 \% \\
\text { (Roosevelt) }\end{array}$ & $-9.1 \%$ & $1.73 \%$ & $1.82 \%$ \\
\hline 1932 & F. Roosevelt & Hoover & $17.4 \%$ & n.a. & F. Roosevelt & $40.84 \%$ & $-17.4 \%$ & $-4.40 \%$ & $-4.10 \%$ \\
\hline 1936 & F. Roosevelt & Landon & $28.1 \%$ & $44.3 \%$ & F. Roosevelt & $37.54 \%$ & $-28.1 \%$ & $1.55 \%$ & $2.12 \%$ \\
\hline 1940 & F. Roosevelt & Wilkie & $33.3 \%$ & $48.0 \%$ & F. Roosevelt & $45.00 \%$ & $-33.3 \%$ & $-3.27 \%$ & $-2.58 \%$ \\
\hline 1944 & F. Roosevelt & Dewey & $20.8 \%$ & $48.5 \%$ & F. Roosevelt & $46.34 \%$ & $-20.8 \%$ & $-0.11 \%$ & $0.26 \%$ \\
\hline 1948 & Truman & Dewey & $88.9 \%$ & $52.7 \%$ & Truman & $47.63 \%$ & $-88.9 \%$ & $-4.56 \%$ & $-2.49 \%$ \\
\hline 1952 & Stevenson & Eisenhower & $54.6 \%$ & $51.0 \%$ & Eisenhower & $55.40 \%$ & $45.4 \%$ & $0.34 \%$ & $-0.93 \%$ \\
\hline 1956 & Stevenson & Eisenhower & $80.0 \%$ & $59.5 \%$ & Eisenhower & $57.76 \%$ & $20.0 \%$ & $-0.99 \%$ & $-1.63 \%$ \\
\hline 1960 & Kennedy & Nixon & $38.5 \%$ & $49.0 \%$ & Kennedy & $49.91 \%$ & $-38.5 \%$ & $0.47 \%$ & $1.29 \%$ \\
\hline 1964 & Johnson & Goldwater & $0.3 \%$ & $36.0 \%$ & Johnson & $38.66 \%$ & $-0.3 \%$ & $0.00 \%$ & $-0.13 \%$ \\
\hline 1968 & Humphrey & Nixon & $54.5 \%$ & $50.6 \%$ & Nixon & $50.40 \%$ & $45.5 \%$ & $0.18 \%$ & $-1.09 \%$ \\
\hline 1972 & McGovern & Nixon & $99.0 \%$ & $62.0 \%$ & Nixon & $61.79 \%$ & $1.0 \%$ & $-0.46 \%$ & $-0.62 \%$ \\
\hline
\end{tabular}




\begin{tabular}{|c|c|c|c|c|c|c|c|c|c|}
\hline 1992 & Clinton & G.H.W Bush & $7.8 \%$ & $43.0 \%$ & Clinton & $46.54 \%$ & $-7.8 \%$ & $-1.02 \%$ & $-0.97 \%$ \\
\hline 1996 & Clinton & Dole & $7.0 \%$ & $44.1 \%$ & Clinton & $45.34 \%$ & $-7.0 \%$ & $2.27 \%$ & $2.30 \%$ \\
\hline 2000 & Gore & G.W. Bush & $61.5 \%$ & $51.1 \%$ & Gore & $49.73 \%$ & $38.5 \%$ & $-0.55 \%$ & $-1.65 \%$ \\
\hline 2004 & Kerry & G.W. Bush & $55.0 \%$ & $50.0 \%$ & G.W. Bush & $51.24 \%$ & $45.0 \%$ & $1.15 \%$ & $-0.11 \%$ \\
\hline \multicolumn{10}{|c|}{ Averages (with standard errors) } \\
\hline \multicolumn{3}{|c|}{ Democrat winner } & $\begin{array}{c}32.8 \% \\
(6.6)\end{array}$ & $\begin{array}{c}46.2 \% \\
(1.7)\end{array}$ & $\mathrm{n}=14$ & $\begin{array}{c}45.2 \% \\
(1.1)\end{array}$ & $\begin{array}{c}-32.8 \% \\
(6.6)\end{array}$ & $\begin{array}{c}-0.71 \% \\
(.57)\end{array}$ & $\begin{array}{c}-0.03 \% \\
(.51)\end{array}$ \\
\hline \multicolumn{3}{|c|}{ As underdog $\left(\mathrm{p}^{\mathrm{Dem}}<.5\right)$} & $\begin{array}{c}59.5 \% \\
(7.4)\end{array}$ & $\begin{array}{c}51.6 \% \\
(1.1)\end{array}$ & $\mathrm{n}=5$ & $\begin{array}{c}48.6 \% \\
(0.4)\end{array}$ & $\begin{array}{c}-59.5 \% \\
(7.4)\end{array}$ & $\begin{array}{c}-1.44 \% \\
(0.82)\end{array}$ & $\begin{array}{c}-0.09 \% \\
(.65)\end{array}$ \\
\hline \multicolumn{3}{|c|}{ As favorite $\left(\mathrm{p}^{\text {Dem }} \geq .5\right)$} & $\begin{array}{c}18.0 \% \\
(4.4)\end{array}$ & $\begin{array}{c}44.7 \% \\
(1.7)\end{array}$ & $\mathrm{n}=9$ & $\begin{array}{c}43.3 \% \\
(1.4)\end{array}$ & $\begin{array}{c}-18.0 \% \\
(4.4)\end{array}$ & $\begin{array}{c}-0.31 \% \\
(.75)\end{array}$ & $\begin{array}{l}0.00 \\
(.74)\end{array}$ \\
\hline \multicolumn{3}{|c|}{ Republican winner } & $\begin{array}{c}76.3 \% \\
(3.5)\end{array}$ & $\begin{array}{c}54.5 \% \\
(1.5)\end{array}$ & $\mathrm{n}=18$ & $\begin{array}{l}55.7 \% \\
(1.17)\end{array}$ & $23.7 \%$ & $\begin{array}{c}+0.76 \% \\
(.27)\end{array}$ & $\begin{array}{c}0.03 \% \\
(.30)\end{array}$ \\
\hline \multicolumn{3}{|c|}{ As underdog $\left(\mathrm{p}^{\mathrm{Rep}}<.5\right)$} & n.a. & n.a. & $\mathrm{n}=0$ & n.a. & n.a. & n.a. & n.a. \\
\hline \multicolumn{3}{|c|}{ As favorite $\left(\mathrm{p}^{\mathrm{Re}} \geq .5\right)$} & $\begin{array}{c}76.3 \% \\
(3.5)\end{array}$ & $\begin{array}{c}54.5 \% \\
(1.5)\end{array}$ & $\mathrm{n}=18$ & $\begin{array}{c}55.67 \% \\
(1.17)\end{array}$ & $\begin{array}{c}23.7 \% \\
(3.5)\end{array}$ & $\begin{array}{c}+0.76 \% \\
(.27)\end{array}$ & $\begin{array}{c}0.03 \% \\
(.30)\end{array}$ \\
\hline
\end{tabular}

Data Sources: Street. Rhode and Strumpf [2004, 2005] provide greater detail about this market. For 1976-1988, we rely on press reports of betting odds with British bookmakers; for 1992-1996, we use data from the Iowa Electronic Markets (although these are predictions of the winner of the popular vote). In 2000 we use data provided by Centrebet, an online bookmaker and for 2004 we use Tradesports data. We were unable to obtain prediction market data for the 1964-1972; our probability assessments for these periods are derived by estimating the following relationship between prediction market prices and two-party predicted vote shares from the final pre-election Gallup poll:

Prediction market price $=\Phi^{-1}($ Poll- $-0.5 / \sigma)$, where $\Phi^{-1}($.$) is the inverse normal cdf.$

Using non-linear least squares, we estimated $\sigma=4.9$, with a standard error of 1.0. Note that our method for estimating a probability is not crucial to the results, since in 1964 and 1972 the eventual winner was at least 20 points ahead in front in the final Gallup poll, while the final poll in 1968 was virtually a dead heat.

Equity Returns: Are measured from the market the close on the day prior to the election to the close the following day. (For most of the sample, financial markets were closed on Election Day). Estimates of returns to a value-weighted return index come from CRSP for 1964-2004 and Schwert [1990] for 18881960, and for 1880-1884, we use Kalinke's [2004] 12 stock average.

Gallup poll data: For 1936-2004 reflect the Gallup organization's final pre-poll projections of the two-party vote share. Historical data are from www.gallup.com.

Election results: Are reported as shares of the popular vote earned by the two most popular candidates. For the 1912 election, Taft, the Republican candidate was effectively the third party, and hence we report Roosevelt as if he were the Republican candidate.

Partisan shock: Measures the change in the probability of a Republican president from the day prior to the election, to the day after. We measure this shock as: $I(\text { Republican President })_{-}-p\left(\right.$ Republican president $\left._{t-1}\right)$, where the pre-election probability of a Republican president comes from political prediction markets. 